\title{
Cloning and nucleotide sequence of an extracellular $\alpha$-amylase gene from Aeromonas hydrophila MCC-1
}

\author{
Ming Chung Chang,* Jing Chyi Chang and Jen Pin Chen $\dagger$ \\ Department of Biochemistry Medical College, National Cheng Kung University, Tainan, Taiwan, Republic of China
}

(Received 26 April 1993; revised 27 July 1993; accepted 10 August 1993)

\begin{abstract}
A gene encoding the extracellular $\alpha$-amylase of Aeromonas hydrophila $\mathrm{MCC}-1$ was cloned and expressed using its own promoter on the recombinant plasmid pCA101. Subcellular fractionation of Escherichia coli JA221 carrying pCA101 revealed that approximately $60 \%$ of the amylase activity was localized in the periplasmic space. The extracellular amylase was purified to homogeneity, identified as an $\alpha$-type and its amino-terminal sequence was determined. Nucleotide sequence analysis predicted a 443 amino acid ORF and 24 amino acids at the amino terminus of the sequence that are not found in the secreted protein. This 24 amino acid sequence has many of the characteristics common to known signal peptides. The predicted amino acid sequence has considerable similarity with mammalian, invertebrate and Streptomycete $\alpha$-amylases. Most of the amino acid residues that are involved in catalytic activity, substrate binding and calcium binding in several $\alpha$-amylases were also present in $A$. hydrophila $\alpha$-amylase at the corresponding positions.
\end{abstract}

\section{Introduction}

Many Gram-negative bacteria possess the capacity to secrete certain proteins into the growth medium. Extracellular proteins produced by these bacteria have to cross an envelope, which is composed of two distinct membranes separated by the periplasm. Although much attention has been focused on the export process, the mechanism by which Gram-negative bacteria secrete proteins across the envelope is not well understood. Several specific and independent export pathways appear to be used for the secretion of different proteins in various Gram-negative bacteria (Pugsley et al., 1990).

Aeromonas hydrophila, a member of the family Vibrionaceae, possesses the capacity to secrete various extracellular proteins, including aerolysin (Howard \& Buckley, 1985), enterotoxin (Chakraborty et al., 1984), phospholipase (Nord et al., 1975), amylase (Gobius \& Pemberton, 1988), acyltransferase (MacIntyre \& Buckley, 1978), chitinase (Yabuki et al., 1986) and proteases (Leung \& Stevenson, 1988), which can play important

\footnotetext{
*Author for correspondence. Tel./fax +88662754697.
}

$\uparrow$ Present address: Council of Agriculture, Department of Food and Agriculture, Taipei, Taiwan, Republic of China.

The nucleotide sequence data reported in this paper have been submitted to GenBank and have been assigned the accession number L19299. roles in pathogenesis, degradation of macromolecules and other interactions with the environment. Because of the significance of these toxins and exoenzymes secreted by $A$. hydrophila, this organism has been chosen for the study of secretion mechanisms. Previous studies have reported that when aerolysin, acyltransferase, protease and amylase structural genes are expressed in Escherichia coli, these exoproteins are secreted only to the periplasm, indicating that specific functions, absent in $E$. coli, were necessary for the second step of transfer through the outer membrane and release into the medium (Chakraborty et al., 1986; Gobius \& Pemberton, 1988; Howard \& Buckley, 1986; Rivero et al., 1990; Thornton et al., 1988). The need for other gene products is supported by the observation that pleiotropic export mutants of $A$. hydrophila have been isolated which accumulate aerolysin and protease in the periplasm (Howard \& Buckley, 1983). Recently, mutants defective in translocation across the outer membrane have been isolated and genes required for the successful translocation of proteins across the cell envelope have been cloned (Jiang \& Howard, 1991, 1992). As an approach to study the secretion of proteins in $A$. hydrophila and E. coli, we have cloned the genes encoding exoproteins from $A$. hydrophila into E. coli (Chang et al., 1992; Chen et al., 1991). In this paper, molecular cloning of an extracellular $\alpha$ amylase from $A$. hydrophila, as well as the secretion and locations of the cloned amylase in $E$. coli are described. The derived amino acid sequence for the encoded 
polypeptide is also compared with those of prokaryotic and eukaryotic origins.

\section{Methods}

Bacterial strains and plasmids. A. hydrophila MCC-1 was used. It was isolated initially in this laboratory from soil samples, and identified by the Culture Collection and Research Center, Food Industry Research and Development Institute, Hsinchu, Taiwan, Republic of China. E. coli JA221 (Beggs, 1978) and E. coli JM109 (Yanisch-Perron et al., 1985) were used as hosts for recombinant plasmids. Plasmid pBR322 (Bolivar et al., 1977) was used in cloning experiments. Plasmids pUC18 and pUC19 (Vieira \& Messing, 1982) were used in subcloning experiments.

Media and culture conditions. E. coli was grown in Luria broth (LB) or on LB agar $(1.5 \%, \mathrm{w} / \mathrm{v})$ (Sambrook et al., 1989). Starch medium contained M9 medium (Sambrook et al., 1989) without glucose, $1 \%$ $(\mathrm{w} / \mathrm{v})$ soluble starch (extra pure, Ishizu Pharmaceutical Co.), $50 \mu \mathrm{g}$ ampicillin $\mathrm{ml}^{-1}, 1 \mathrm{mM}-\mathrm{CaCl}_{2}, 1 \mathrm{~mm}-\mathrm{MgSO}_{4}$, and $1.5 \%$ agar. Cleared zones after flooding with iodine solution $\left(0.05 \% \mathrm{I}_{2}\right.$ and $0.5 \%$ KI) indicated starch hydrolysis. $A$. hydrophila strains were grown at $30{ }^{\circ} \mathrm{C}$ in LB or starch medium. Linear malto-oligosaccharides [glucose (G1), maltose (G2), maltotriose (G3), maltotetraose (G4), maltopentaose (G5), maltohexaose (G6)], $\alpha$-amylase from Bacillus species and $\beta$-amylase from barley were purchased from Sigma.

Construction and screening of the DNA library. All DNA manipulations were carried out in accordance with manufacturers' instructions and as described by Sambrook et al. (1989). A. hydrophila chromosomal DNA was prepared as described previously (Chen et al., 1991). For the construction of the DNA library, chromosomal DNA from $A$. hydrophila was partially cleaved with Sau3A, and fragments of 5-20 kb were isolated by sucrose density gradient centrifugation. The DNA fragments were ligated with T4 DNA ligase to BamHI-digested plasmid pBR322, and the ligation mixture was used to transform E. coli JA221 cells made competent by treatment with $\mathrm{CaCl}_{2}$. After replica-plating on LB agar medium containing ampicillin and tetracycline, about $90 \%$ of the clones were tetracycline sensitive $\left(\mathrm{Tc}^{\mathrm{s}}\right)$, indicating insertion of a foreign DNA fragment. A total of 25000 ampicillin-resistant $\left(\mathrm{Ap}^{\mathrm{r}}\right) \mathrm{Tc}^{\mathrm{s}}$ transformants were kept in a collection. The gene bank was used to transform E. coli JA221 and transformants were selected on amylaseselective plates containing starch medium supplemented with $20 \mu \mathrm{g}$ thiamine $\mathrm{ml}^{-1}$ and $0.01 \%$ each of leucine, tryptophan, and threonine. Although $E$. coli has been shown to contain an $\alpha$-amylase (MalS), which is able to degrade small malto-oligosaccharides (Freundlieb \& Boos, 1986), E. coli JA221 transformants grew poorly on amylaseselective plates. Colonies growing well on these plates after $16 \mathrm{~h}$ of incubation at $37^{\circ} \mathrm{C}$, were isolated and amylase-positive clones were further identified by the production of cleared zones after flooding with iodine solution.

Enzyme activity measurements. Amylase activity was determined at $37^{\circ} \mathrm{C}$, using $0.5 \%$ soluble starch as a substrate in $50 \mathrm{~mm}$-sodium phosphate buffer, $\mathrm{pH} 6.8$, containing $5 \mathrm{~mm}-\mathrm{CaCl}_{2}$. The release of reducing sugar from soluble starch was measured with 3,5-dinitrosalicylic acid. One unit of amylase was defined as the amount of enzyme producing $1 \mu \mathrm{mol}$ of reducing sugar in $1 \mathrm{~min}$ as a result of hydrolysis of soluble starch, assayed using glucose as the standard. $\beta$-Galactosidase and $\beta$-lactamase activities were assayed as described previously (Chang et al., 1992). Protein concentrations were determined using a protein assay kit (Bio-Rad) with bovine serum albumin as standard.

Cellular fractionation. Extracellular, periplasmic and cytoplasmic cell fractions were prepared according to Cornelis et al. (1982). An overnight culture of $E$. coli was inoculated into $200 \mathrm{ml}$ of starch medium supplemented with $20 \mu \mathrm{g}$ of thiamine $\mathrm{ml}^{-1}$ and $0.01 \%$ each of leucine, tryptophan and threonine. The culture was incubated at $37^{\circ} \mathrm{C}$ with vigorous shaking. The cells were harvested at the early stationary phase and washed with $10 \mathrm{~mm}-\mathrm{Tris} / \mathrm{HCl}(\mathrm{pH} 80)$ containing $25 \%$ $(\mathrm{w} / \mathrm{v})$ sucrose. The washed cells were suspended in the same solution with $1 \mathrm{~mm}$-EDTA, and the suspension was shaken for $10 \mathrm{~min}$ at room temperature. After centrifugation at $6000 \mathrm{~g}$ for $15 \mathrm{~min}$, the cells were quickly and vigorously suspended in ice-cold water. The suspension was further shaken for $10 \mathrm{~min}$ at $4{ }^{\circ} \mathrm{C}$ and centrifuged at $8000 \mathrm{~g}$ for $10 \mathrm{~min}$. Cells were resuspended in $10 \mathrm{~mm}$-Tris/ $\mathrm{HCl}(\mathrm{pH} 8.0)$ and disrupted by sonication. The extracellular enzyme fraction was the sum of the activities in the culture supernatant, and the wash. The periplasmic fraction was the activity found in the supernatant after treatment with cold water. The cytoplasmic fraction was the activity found in the supernatant after sonication.

Purification, amino-terminal amino acid sequence and amino acid analysis of amylase. A. hydrophila or E. coli JA221 harbouring plasmids pBR322 or pCA101 was grown to stationary phase in $21 \mathrm{LB}$ medium containing $50 \mu \mathrm{g}$ ampicillin $\mathrm{ml}^{-1}$, and the extracellular and periplasmic cell fractions were prepared as described above. $\alpha$-Amylases from the culture supernatant of $A$. hydrophila and from $E$. coli periplasmic or extracellular preparations were purified as follows. The starting material was fractionated with finely powdered ammonium sulphate, and the $25-50 \%$ of ammonium sulphate-precipitated material was resuspended in $30 \mathrm{~mm}$-Tris/ $\mathrm{HCl}$ buffer $(\mathrm{pH} 8.0)$ before being applied to a PD-10 column (Pharmacia) to remove salts. The desalting materials were applied to a DEAE-Sepharose CL-6B column $(2.6 \times 15 \mathrm{~cm})$ equilibrated with $30 \mathrm{~mm}$-Tris/ $\mathrm{HCl}$ buffer $(\mathrm{pH} 8.0)$. The enzyme was eluted with $500 \mathrm{ml}$ of a linear gradient of $0-500 \mathrm{~mm}-\mathrm{NaCl}$ in the same buffer. The eluted enzyme fraction was concentrated on a membrane (YM3; Amicon) and then subjected to gel filtration on a Sephadex G100 column $(2.2 \times 100 \mathrm{~cm})$ that had been equilibrated with $30 \mathrm{~mm}$ Tris/ $\mathrm{HCl}$ buffer ( $\mathrm{pH} \mathrm{8.0)}$. The $\alpha$-amylase was eluted from the column with the same buffer at a flow rate of $20 \mathrm{ml} \mathrm{h}^{-1}$, and the active fractions were collected. Purification was monitored by SDS-PAGE (Laemmli, 1970). The amino-terminal amino acid sequence of $\alpha$-amylase was determined with an ABI 477A-120A Protein Sequencer after extensive dialysis of the sample against distilled water. The $\alpha$-amylase was hydrolysed in vacuo with $6 \mathrm{M}-\mathrm{HCl}$ at $150^{\circ} \mathrm{C}$ for $1.5 \mathrm{~h}$, and amino acid analysis was carried out with a Beckman System 6300 High Performance Amino Acid Analyser.

$D N A$ sequencing. All sequences were determined on denatured double-stranded DNA templates by the dideoxy-chain termination method (Sanger et al., 1977), using a Sequenase 2.0 DNA sequencing kit (USB) and $\left[\alpha-{ }^{35} \mathrm{~S}\right] \mathrm{dATP}$ [sequencing grade, $12.5 \mathrm{mCi} \mathrm{m}^{-1}$ (463 $\mathrm{MBq} \mathrm{ml}^{-1}$ ); specific activity, $\quad 1000-1500 \mathrm{Ci} \mathrm{mmol}^{-1}$ $55.5 \mathrm{TBq} \mathrm{mmol}{ }^{-1}$ ); New England Nuclear]. Universal and reverse primers were used to obtain the initial sequences within the inserts, and then specific primers for the sequences within the inserts were generated. Conditions for DNA sequencing were as described in the Sequenase brochure (USB). Denaturing PAGE $(6 \%, \mathrm{w} / \mathrm{v}$, polyacrylamide) at $60 \mathrm{~W}$ was used to separate the reaction products. The gels were exposed to X-ray film (Kodak Omat-AR) overnight. DNA was sequenced in both directions. In some cases, dITP was used in place of dGTP for a more reliable reading through regions of high $\mathrm{G}+\mathrm{C}$ content.

\section{Results}

Cloning of A. hydrophila DNA encoding an extracellular amylase

To clone the gene encoding the extracellular amylase of A. hydrophila MCC-1, a genomic library was constructed in $E$. coli JA221. Two amylase-positive clones, designated 


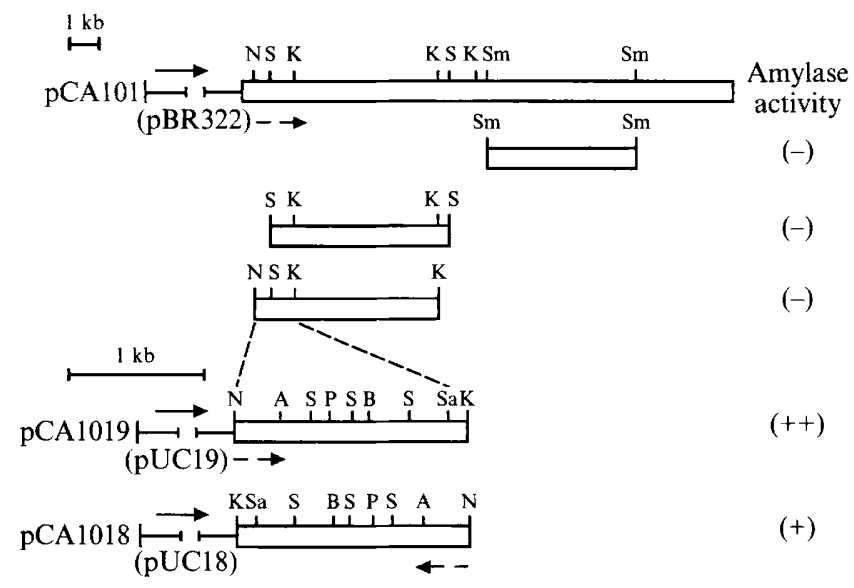

Fig. 1. Restriction endonuclease maps of plasmid clones harbouring the amylase gene. A, ApaI ; B, BstXI; K, KpnI; N, NheI; P, PvuII; S, SacI; Sa, SalI; Sm, SmaI; Sp, SphI. Boxes indicate A. hydrophila DNA; thin lines indicate DNA from the plasmid vectors pBR322, pUC18 or pUC19; solid arrows indicate the direction of transcription of the tetracycline promoter (pCA101) or the lac $Z p$ promoter (pCA1019 and pCA1018); dashed arrows indicate the direction of the putative promoter of the cloned gene. Varying levels of activity are represented by + and $++;-$ indicates no activity.

JA221(pCA101) and JA221(pCA102), were detected in approximately 5000 transformants screened. The DNA inserts of the hybrid plasmids pCA101 and pCA102 were characterized by digestion with restriction enzymes, and physical maps showed that the two plasmid inserts were identical except that the pCA101 insert $(9 \cdot 0 \mathrm{~kb})$ was $2 \mathrm{~kb}$ smaller than that of pCA102. Subcloning of various restriction fragments indicated that the amylase gene was located on the $1.7 \mathrm{~kb}$ NheI-KpnI fragment of pCA101. This fragment was subcloned into pUC18 and pUC19 yielding plasmids pCA1018 and pCA1019, respectively (Fig. 1). Although the insert DNA fragment in pCA1018 was oriented in the opposite direction to that in pCA1019 with respect to the lac promoter, both plasmids expressed amylase activity in E. coli. In the presence of IPTG, larger colonies were observed on starch medium plates with E. coli JM109(pCA1019) than with JM109(pCA1018).

\section{Cellular distribution of amylase in E. coli}

Amylase from $A$. hydrophila was secreted into the medium. Only a small amount of amylase activity was measured in the cells (data not shown). To investigate whether amylase expressed from the cloned gene could be secreted by $E$. coli , the localization of amylase activity in $E$. coli JA221 (pCA101) in early stationary phase was determined. As a control, E. coli JA221 harbouring pBR322 was cultivated under the same conditions. Cell fractions were also assayed for $\beta$-lactamase and $\beta$ galactosidase activities as markers for periplasmic and cytoplasmic enzymes, respectively. Table 1 shows that essentially no enzymic activities were detected in the culture supernatant of $E$. coli JA221(pBR322); $\beta$ lactamase was found predominantly in the periplasmic fraction and $\beta$-galactosidase in the cytoplasmic fraction. However, about $40 \%$ of total $\beta$-lactamase and $30 \%$ of total amylase activities were found in the extracellular fraction of $E$. coli JA221(pCA101), and approximately $90 \%$ of $\beta$-galactosidase in the cytoplasmic fraction.

\section{Purification and properties of amylase}

The $M_{\mathrm{r}}$ value of the purified enzyme from $A$. hydrophila was estimated to be 46000 by SDS-PAGE (data not shown). A protein with an identical $M_{\mathrm{T}}$ value was purified from osmotically shocked cells and culture medium of E. coli JM109 transformed with pCA1019 (data not shown).

Thin-layer chromatographic analysis revealed that the products of soluble starch hydrolysis by the purified cloned amylase from E. coli JM109(pCA1019) were mainly G2 and G3. When G6 was used as a substrate, hydrolysis products of the cloned amylase or $A$.

Table 1. Distribution of amylase and marker enzymes in early stationary phase growth of E. coli JA221 ( $p C A 101)$ and E. coli JA221(pBR322)

Experiments were performed in triplicate, and the ranges of values are given.

\begin{tabular}{llccc}
\hline \hline & & \multicolumn{2}{c}{ Enzyme activity (percentage total enzyme activity) } \\
\cline { 3 - 5 } Plasmid & Fraction & Amylase & $\beta$-Lactamase & $\beta$-Galactosidase \\
\hline \multirow{2}{*}{ pBR322 } & Supernatant & $-*$ & $10-16$ & - \\
& Periplasmic & - & $80-84$ & - \\
& Cytoplasmic & - & $4-6$ & 100 \\
& Supernatant & $21-33$ & $36-44$ & $4-8$ \\
& Periplasmic & $54-69$ & $48-54$ & $0-2$ \\
& Cytoplasmic & $10-13$ & $8-10$ & $90-94$ \\
\hline \hline
\end{tabular}

${ }^{*}$ E. coli JA221(pBR322) cells contained no detectable amylase activity. 
GATCTCGCACCGATCTGCCCCCCTCTGCCCCCTCCTGCTGCCACCGAATGGCATGAAAGC

ATTTTCATTCACATTTCTTAATTAATTCAGCCTGTTCGATTTTCAACCACATCGATTTCA TGAATGCTACGGAGCTGAACGAGGTTGTTTGTTTCCGTTCGACTACACGACAGTTATAC 180 -35 -10

GTCAATAACAAGATCGAAGGGAAAATCGTCATGCACAACACACTGTTTCGAACCGCCCTG RBS METH isAsnThrLeuPheArgThrAlaLeu

CTGGCGGCGGCACTCGGCTCTTTCAGCCACACTGCCAGCGCCGAAGGAGTCATGGTTCAC LeuAlaAlaAlaLeuglySerPheSerHisThrAlaSerAlagluglyValMetValH is 24

CTGTTCGAATGGAAGTTCAACGACATCGCCAACGAGTGCGAGACCGTGCTCGGGCCCAAG LeuPheGluTrpLysPheAsnAspI leAlaAsnGluCysGluThrValLeuGlyProLys

GGGTTCGGTGGCGTCCAGGTCAGCCCACCCGCCGAGCACAAGCAGGGCAGCCAGGTCTGG GlyPheGlyGlyValGlnValSerProProAlagluHisLysGlnglySerGlnValTrp

TGGACCGTCTATCAACCGGTCAGCTACAAGAATTTCAACAGCTTCGGCGGATGCGAGGCA TrpThrValTyrGInProValSerTyrLysAsnPheAsnSerPheGlyGlyCysGluAla

GAGCTCAGGAGCATGATCGCCCGCTGCAACGCGGCCGGGGTCAAGGTCTATGCCGACGCC GluLeuArgSerMet I leAlaArgCysAsnA laA laGlyVaILysValTyrA laAspAla

GTCTTCAACCACATGGCATCGGGTTCGGGCACCGCCACCGGCGGCGGCAGCTACAACTCG ValPheAsnHisMetAlaSerGlySerGlyThrAlaThrGlyGlyGlySerTyrAsnSer

GGGCAATACCAATATCCCCAGTTCGGCTACAACGACTTCCATCACAGCGGCGACATCACC GlyGlnTyrGInTyrProGlnPheGlyTyrAsnAspPheHisHisSerGlyAspI leThr

AACTACGGTGACAGCAACAACGTCTGGAACGGCGCCCTCTACGGCCTGCCGGACCTCAAT AsnTyrGlyAspSerAsnAsnValTrpAsnG lyAlaLeuTyrGlyLeuProAspLeuAsn

ACCGGCTCATCCTACGTCCAGGATCAGATCGCCACCTACATGAAGACCCTGCTCGGCTGG ThrGlySerSerTyrValGlnAspG InI leAlaThrTyrMetLysThrLeuLeuGlyTrp

GGCGTGGCGGGCTTTCGCATCGATGCGGCCAAGCACATGGCGCCGGCCGATGTGAAGGCC GlyValAlaGlyPheArgI leAspAlaAlaLysHisMetAlaProAlaAspValLysAla

ATCCTCGACAAGGCAGGCAGCCCCAGGGCCTACCTGGAGGTGATCGGCGCAGGCGGGGAG I leLeuAspLysA laGlySerProArgAlaTyrLeuGluValI leGlyAlaGlyGlyGlu

TCCCCCGACATTCAGCCGGGCCGCTACACCTACATCGACACCGTCACCGAGTTCAAATAC SerProAspI leSerProGlyArgTyrThrTyrI leAspThrValThrGluPheLysTyr

GGCACCGATCTCGCCGCCAACTTCAACGGCCAGATCAAGAACCTCAAAACCCTGGGCGAG 1020 GlyThrAspLeuAlaAlaAsnPheAsnGlyGlnI leLysAsnLeuLysThrLeuGlyGlu 270

AGCTGGGGCCTGCTCCCCTCCAACAAGGCCTTCGTCTTCGTGGACAACCACGATCCCGAA 1080 SerTrpGlyLeuLeuProSerAsnLysAlaPheValPheValAspAsnHisAspProGlu 290

CGCGCGCACGGCGGTGGCGGCATGCTCACCTTCATGCAGGGTGCCCGCTACGATCTGGCC 1140 ArgAlaHisGlyGlyGlyGlyMetLeuThrPheMetGlnGlyAlaArgTyrAspLeuAla 310

AACACCTTCATGCTGGCCTGGCCCTATGGCTGGAAGCAGGTGATGTCGGCGTATCGCTTT 1200 AsnThrPheMetLeuAlaTrpProTyrGlyTrpLysG InValMetSerAlaTyrArgPhe 330

GAAAACATGGGCACCTATGAAACCGACAAGGGGGCGCCGGGCAGCACGCCCTGCACGGAC 1260 GluAsnMetGlyThrTyrGluThrAspLysGlyAlaProGlySerThrProCysThrAsp 350

AGCCAGTGGAACTGCGAACAGCGCCGACCGACCATCATGAACATGGTCCTGTTCCGCAAC 1320 SerGlnTrpAsnCysGluGlnArgArgProThrIleMetAsnMetValLeuPheArgAsn 370

CGGACCGAAGGCCAGCCCGTCAGCAACTGGTGGGACAACGGCAACAACCAGATCGCCTTC 1380 ArgThrGluGlyGlnProValSerAsnTrpTrpAspAsnglyAsnAsnglnIleAlaPhe 390

AGCCGCGGTACAAGGGCTTCGTCGCCATCAACAACGAGAGCGGCACGCTGGTGGCCTCGG 1440 SerArgGlyThrArgAlaSerSerProSerThrThrArgAlaAlaArgTrpTrpProArg 410

TGCAGACGCTCGCGGCCGGCGAGTACTGCAACCTCCTGGGGGGCAATGACTACTGCAGCG 1500 CysArgArgSerArgProAlaSerThrAlaThrSerTrpGlyAlaMetThrThrAlaAla 430

GCGGTTATGTCACCGTCGACGGCAGCGGCAAGGCCAGCCTGAACGATTCCCCGGCATGAA 1560 AlaValMetSerProSerThrAlaAlaAlaArgProAla***

GCGGCCGCCATCATGCCGGTTGCACCAAGGCCAGCCCCTGCGGCGGTTCCGTCCTGCCGG 1620

\section{0}




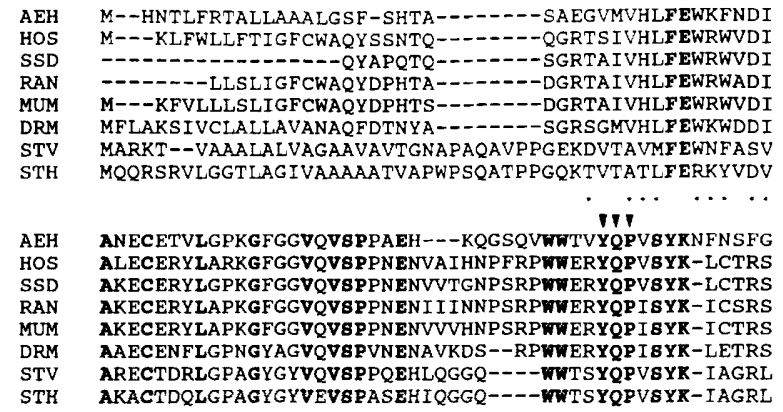

GCEAELRSMIARCNAAGVKVYADAVFNHM---ASGSGTATGGGSY-NSGQ GNEDEFRNMVTRCNNVG-RIYVDAVINHYCGNAVSAGTSSTCGSYFNPGS GNEDEFRDMVTRCNNVGVRI YVDAVINHMCGSGAAAGTGTTCGSYCNPGN GNENEFKDYVTRCNNVGVRI YVDAVINHMCGSGNSAGTHSTCGSYFNPNN GNEDEFRDMVTRCNNVGVRI YVDAVINHMCGAGNPAGTSSTCGSYINPNN GNEEQFASMVKRCNAVGVRTYVDVVFNHMAADGGTYGTGGSTAS---PSS 作 GDRDAFASMVSACHAAGVKVIADAVVNHM---AAGSGRHHA--QY---TK ...........

YQYPQFGYN--DFHH-_._-SGDITNYGDSNVWNG-ALYGLPDLNTGS RDFPAVPYSGWDFNDGKCKTGSGDI ENYNDATOVRD-CRLSGLLDLALGK REFPAVPYSAWDFNCNGKKTASGGIESYNDPYQVRDGCQVL-LLDLALEK REFSAVPY SAWY FNDNKCN---GEINNYNDANQVRN-CRLSGLLDLALDK REFPAVPYSAWDFNDNKCN ---GEIDNYNDAYQVRN-CRLTGLLDLALEK K-YPGVPYSSLDFN------PTCAISN YNDANEVRN-CELVGLRDLNQGN YDYPGL-YSGSDMD--DCRAT---ISNYQDRANV-QNCELVQLPDLDTGE
YNYPGF-YQDQTFH--GCRKS---ISDYTNRDDV-QTCELVDLADLGTGS$$
\cdot \quad \cdot \cdots
$$$$
\text { DAAR }
$$

SYVQDQIATYMKTLLGWGVAGFRIDAARHMAPADVKAILDK-DYVRSKIAEYMNHLIDIGVAGFRIDASKHMWPGDIKAILDKLHNLNSNWDYVRSMIADY LNKLIDIGVAGFRIDASRHMWPGDIKAVLDKLHNLNTNWDYVRTKVADYMNNLIDIGVAGFRLDAAREMWPGDIKAVLDKLHNLNTKWDYVRTKVADYMNHLIDIGVAGFRI DAAKRMWPRDIKAVLDKLHNLNTKWSYVQDKVVEFLDHLIDLGVAGFRVDAAKBMWPADLAVIYGRLKNLNTDHG DHVRGKIAGYLNDLASLGVDGFRIDAAKMMPAADLANIKSRLTNPNVFWK DYVRTTIAGYL-GLRSLGVDGFRIDAARHI SATDLAAVKGKMKDPG-FWV . . . . . . . . . . .

-AGSPRAYL--EVIGAGGESPDISPGRYTY IDTVTDFKYGTDLAANFN--AGSPRAYL--EVIGAGGESPDISPGRYTYIDTVTDFKYGTDLAANFN-FPEGSKPFIYQEVIDLGGEP--IKSSDYFGNGRVTEFKYGAKLGTVIRKW FPAGSRRF I FNEVIDLGGEA--IKGSEYFSNGRVTEFKYGAKLGTVVRKW FSOGSRPFI FQEVIDLGGEA--IKGSEYFGNGRVTEFKYGAKLGTVIRKW FASGSKAYIVOEVIDMGGEA--ISKSEYTGIGAITTFRHSDSIGKVFR-FASGSKAY IVQEVIDMGGEA--ISKSEYTG IGA ITEFRHSDSIGKVFR-. I.II.

$$
\text { C }
$$

-GQIKNLKTLGESWGLLPSNKAFVFVDNHDE ERAHGGGG--MLTFMOGA NGEKMSYLKNWGEGWGFMPSDRALVFVDNHDNQRGHGAGGASILTFWDAR SGEKMSYLKGPLKGYGLMP SDRALVFVDNHDNQRGHGAGGASILTFWDAR NGEKMSY LKNNGEGWG FVPTDRALVFVDNHDNQRGHGAGGASI LTFWDAR NGEKMSYLKNWGEGWGLVPSDRALVFVDNHDNQRGHGAGGSSILTFWDAR GLDQLQYLTNWGTAWGFAASDRSLVFVDNHDNQRGHGAGGADVLTYKVPK QGEKLSYLKNFGEAWGHMPSGQSGVFVDNHDTERG----GDTLSYKDGA
QSGNIAQLKSVAD--GKLWQRQART FVDNWDTERN-----GSTLTYKDGA

....... ...... IV. .

RYDLANTFMLAWPYGWKQVMSAYR----FENM----------GTYET LYKMAVGFMLAHPYOHTRVMSSYRWPRY FENGKDVNDWVGPPNDNGVTKE LYKVAVGFXLAHPYGFTRVMBS YRWARN FVNGNDVNDWIGPPNNNGVIKE MYKMAVGFMLAHPYGFTRVMSSYRRTRNFQNGKDVNDWIGPPNNNGVTKE MYKMAVGFMLAHPYGFTRVMBSYRRTRNFQNGKDVNDWIGPPNNNGVTKE MYKMAVGFMLAHPYGFTRVMSSYRWNRNFQNGKDQNDWIGPPNNNGVTKE
QYKMASAFMLAHPFGTPRVMSSFS----FTDTDQ-----GPPTTDGHNIA QYKMASAFMLAHPFGTPRVMBSFS----FTDTDQ-----GPPTTDGHNIA
NYTLASVFHLAWPYGSPDVHSGY EWT-----DKDA----GPPNNGQV--NYTLASVFHLAWPYGSPDVHSGYEWT-----DKDA----GPPNNGQV---
AYTLANVFMLASPYGSPNVY 8 GYEWT-----DKDA----AAGGST---AYTLANVFMLASPYGSPNVY

DKGAPGSTPCTDSQWNCEQRRPT IMNMVLFRNRTEGQPVSNWWDNGNNQI VTINPD-TTCGN-DWVCEHRWRQIRNMVNFRNVVDGQPFTNW YDNGSNQV VTINAD-TTCGN-DWVCEHRWRNIRNMVWFRNVVDGQPFANWWDNGSNQV VTINPD-TTCGN-DWVCEHRWRNIRNMVAFRNVVNGQPFANWWDNGSNQV VTINADDTTCGN-DWVCEHRWRQIRNMVAFRNVVNGQPF SNWWDNNSNQV SPI FNSDNSCSG-GWVCEHRWRQIYNMVAFRNTVGSDEIQNWWDNGSNQI -_.--NACYTDGWKCQHAWREISSMVAFRNTARGQAVTNWWDNGNNAI GWTDAAKREITGMVGRNAVGSAELTNWWDGGRP
$\ldots \ldots$
$-\ldots$$$
\cdots
$$

AFSRGTRA--- AFGRGNRGF IVFNNDDWTF SLTLOTGLPAGTY CDVISGDKI_......AFGRGNRGF IVFNDDDQLWSGTLQTGLPGGTYCDVISGDKVAFSRGNRGF IVFNNDDNALSSTLQTGLPAGTYCDVI SGDKV-.---.--. AFSRGNRGFIVFNNDDWALSATLQTGLPAGTYCDVISGDKV

SFSRGSRGFVAFNNDNYDLNSSLOTGLPAGTYCDVISGSKS-

AFGRGSKAYVAINHETSALTRTFQTSLPAGSYCDV---OSNTPVTVNSSG AFARSDKGFVALNNGDAALTOTFATSLPAGTYCDVVHAASSCDGDTVTVG
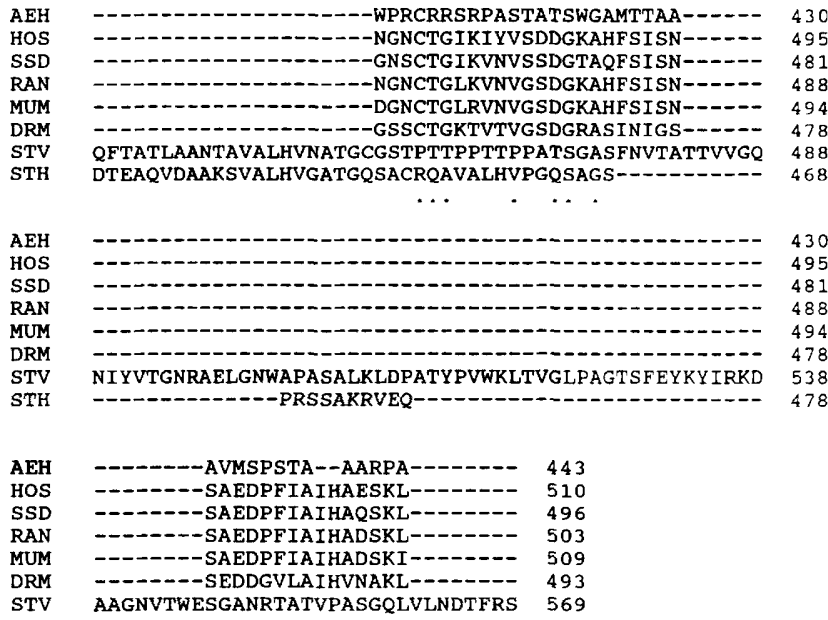

Fig. 3. Optimal alignment of eight $\alpha$-amylases. The amino acid sequences of $\alpha$-amylases from $A$. hydrophila (AEH), Homo sapiens (HOS), Sus scrofa domestica (SSD), Rattus norvegicus (RAN), Mus musculus (MUM), Drosophila melanogaster (DRM), Streptomyces venezuelae (STV), and S. hygroscopicus (STH) are shown. The four previously recognized conserved regions (I-IV) are underlined. Amino acid residues which are identical among all the shown sequences are shown by bold letters, and those possibly involved in substrate or calcium binding are denoted by arrowheads. Dots indicate the location of residues which are the same in at least five of the eight $\alpha$-amylase sequences. Dashes represent gaps introduced during the alignment process. Numbers refer to the amino acid located at the end of each line.

hydrophila amylase were mainly $\mathrm{G} 3$, with some $\mathrm{G} 2$, and a little G4 and G1 (data not shown). Therefore, both enzymes belong to the $\alpha$-type. The cloned $\alpha$-amylase purified from E. coli JM109(pCA1019) has the same maximum activity at $\mathrm{pH} 7.0$ and $37^{\circ} \mathrm{C}$, and the same amino-terminal sequence (Glu-Gly-Val-Met-Val-HisLeu-Phe-Glu-Trp) as that of $A$. hydrophila $\alpha$-amylase.

\section{Sequence analysis of the $\alpha$-amylase gene}

The complete nucleotide sequence of the $1.7 \mathrm{~kb}$ NheI$K p n I$ fragment encompassing the $x$-amylase gene was determined on both strands. The nucleotide and predicted amino acid sequences of the ORF encoding $\alpha$ amylase are shown in Fig. 2. This ORF, starting from ATG at nucleotide number 211 and ending in TAA at nucleotide 1539 , encoded a polypeptide of 443 amino acids with an $M_{\mathrm{r}}$ value of 48290 . The deduced sequence of the first 24 amino acids has the characteristics of a bacterial signal sequence (Von Heijne, 1983). Cleavage of the signal sequence would give a mature protein of $M_{\mathrm{r}}$ 45819 , which is in reasonable agreement with the size derived from SDS-PAGE. Also, amino acids 25-34 correspond exactly with the amino-terminal amino acid sequence of the purified extracellular amylase. The amino acid compositions of $\alpha$-amylase, calculated from the 
deduced amino acid sequence, approximately matched those determined chemically with purified enzymes from the $E$. coli transformant (data not shown).

On the basis of homology to the E. coli promoter consensus sequence (McClure, 1985), putative promoter sequences were tentatively assigned to positions 152 through $157(-35)$, and 176 through $181(-10)$. Between the -10 and -35 regions are 18 nucleotides, the optimal spacing for such regions in this class of promoter sequences. A possible ribosomal binding site (RBS; Shine-Dalgarno sequence) (Shine \& Dalgarno, 1974; Stormo et al., 1982), was found to be 9 bp upstream of the presumptive start codon. The translational stop codon TAA is followed by a stable hairpin structure (free energy of $-16.8 \mathrm{kcal} \mathrm{mol}^{-1}$ ). This structure would be expected to make it an efficient transcriptional terminator.

\section{Codon usage patterns of the $\alpha$-amylase}

The $\mathrm{G}+\mathrm{C}$ content of the coding region for the $A$. hydrophila MCC-1 $\alpha$-amylase gene was $63 \mathrm{~mol} \%$, whilst that of the third position of the codons was higher $(83 \mathrm{~mol} \%)$. These values are nearly identical to those for glycerophospholipid-cholesterol acyltransferase (GCAT) [62 and $82 \mathrm{~mol} \%$, respectively (Thornton et al., 1988)], amylase [62 and $82 \mathrm{~mol} \%$, respectively (Gobius $\&$ Pemberton, 1988)] and deoxyribonuclease (DNAase) [63 and $87 \mathrm{~mol} \%$, respectively (Chang et al., 1992)], and are a little higher than that for aerolysin [58 and $72 \mathrm{~mol} \%$, respectively (Howard et al., 1987)] from this species. The codon usage frequence in the $\alpha$-amylase gene is similar to the pattern for the aforementioned genes of this species (data not shown).

\section{Comparison of amino acid sequence with other $\alpha$-amylases}

Analysis of the predicted polypeptide sequence of the $\mathrm{ORF}$ for homology to other sequences in the GenBank database, using the FASTP algorithm of Lipman \& Pearson (1985), revealed significant homology to a number of $\alpha$-amylases from both prokaryotes and eukaryotes. There was a remarkable degree of similarity with $\alpha$-amylases from mammalian, invertebrate and streptomycete sources (data not shown). Fig. 3 shows that the $A$. hydrophila $\alpha$-amylase amino acid sequence is similar to those from Homo sapiens (human salivary $\alpha$ amylase; Nishide et al., 1986), Sus scrofa domestica (pig pancreas; Kluh, 1981), Rattus norvegicus (Norway rat pancreas; MacDonald et al., 1980), Mus musculus (mouse pancreas; Hagenbuechle et al., 1980), Drosophila melanogaster (Boer \& Hickey, 1986) and Streptomyces species (Hoshiko et al., 1987; Virolle et al., 1988). In addition to regions corresponding to the four highly conserved regions (regions I, II, III and IV) reported for other $\alpha$ amylases (Nakajima et al., 1986; Rogers, 1985), there are a number of other highly conserved regions and residues present in these $\alpha$-amylases (Fig. 3). These regions include a sequence of Phe-Glu-Trp (positions 32-34 in $A$. hydrophila $\alpha$-amylase), which was suggested as a possible candidate for interaction with the tendamistat inhibitor (Hofmann et al., 1985).

From the three-dimensional structure of Aspergillus oryzae (Taka A) amylase, Matsuura et al. (1984) proposed that Glu-230 of region III and Asp-297 of region IV were the important catalytic residues; Tyr-82, Gln-84, Thr-85 (Pro in most $\alpha$-amylases), Ile-152, Tyr155, Val-161, Thr-170 (Leu in most other sequences), Leu-173 and Asp-175 were likely to be involved in substrate binding. Similarly, Buisson et al. (1987) proposed for porcine pancreatic amylase that Asp-197 and Asp-300 (in regions II and IV, respectively) were the catalytic residues, and that Asn-100 (in region I), Asp159, Asp-167 and His-201 (in region II) were the calciumbinding residues. All residues corresponding to these catalytic and substrate binding residues, and three of four calcium-binding residues are clearly present in A. hydrophila $\alpha$-amylase (Fig. 3).

\section{Discussion}

The gene encoding the extracellular amylase of $A$. hydrophila MCC-1 has been successfully cloned into $E$. coli, and the gene product readily expressed in $E$. coli under the control of its own promoter. The nucleotide sequence analysis revealed a single ORF of 1329 nucleotides. The deduced $M_{\mathrm{r}}$ value of the mature protein, 46000 , correlates well with the value determined by SDS-PAGE of the purified $\alpha$-amylase from $A$. hydrophila. There were no apparent differences in the enzymic characteristics of the purified $\alpha$-amylase from $A$. hydrophila and that obtained from $E$. coli containing the cloned amylase gene. Moreover, sequences of the 10 amino-terminal amino acids of both proteins were identical, and matched residues 25-34 of the deduced amino acid sequence. A 24 amino acid amino-terminal sequence has many of the characteristics common to the signal sequences of proteins processed by the signal peptidase I type of pathway (Von Heijne, 1988). It has a positively charged amino acid (His) adjacent to a methionine residue at the amino terminus, followed by a hydrophobic amino acid core and Ala at the carboxy terminus. The cleavage sites between Ala and Glu, and the surrounding residues are in accordance with the -3 , -1 rule proposed by Von Heijne (1984).

Cloning in $E$. coli of an amylase gene from another $A$. hydrophila strain, JMP636, has been reported (Gobius \& 
Pemberton, 1988), but whether this amylase belongs to the $\alpha$-type is unknown. Our cloned $\alpha$-amylase, which is identified as an $\alpha$-type, apparently differs from the amylase cloned from strain JMP636. Based on the nucleotide or amino acid sequence, significant divergence exists in JMP636 amylase (data not shown), even though the similarity of codon usage frequencies in the translated reading frame of both amylase genes was observed. Because there is insufficient information on the enzymic properties of these two $A$. hydrophila amylases, it is not clear whether $A$. hydrophila secretes two amylases having the same size but differing considerably in enzymic properties and sequence, or whether the strain used by us or by Gobius \& Pemberton is not hydrophila. A distinctive property is that the JMP636 amylase gene product was only exported to the periplasm in E. coli. Some of the cloned $\alpha$-amylase was present in the supernatant fluid of cells in early stationary phase (Table 1).

Based on analysis of the deduced amino acid sequence of the JMP636 amylase gene and localization of the cloned amylase in E. coli, Gobius \& Pemberton (1988) predicted that this amylase contained an amino-terminal signal peptide which was removed during its translocation across the cytoplasmic membrane of $E$. coli. They proposed that this enzyme does not contain sufficient information in either the signal peptide or the mature protein to ensure translocation across the outer membrane of $E$. coli. Our data indicate that $\alpha$-amylase contains a putative signal peptide and that the periplasmic form of the $\alpha$-amylase assumes a conformation identical to that of $\alpha$-amylase secreted by $A$. hydrophila MCC-1. The presence of extracellular amylase activity could be due to leakage of the periplasmic proteins through the outer membrane into the supernatant fluid, since approximately $35 \%$ of the periplasmic control enzyme, $\beta$-lactamase, was also detected in the extracellular fluid. In contrast, the $\beta$-galactosidase was predominantly detected in the cytoplasmic fraction, indicating that leakage of cytoplasmic proteins did not occur. These results suggest that $\alpha$-amylase readily translocates protein across the cytoplasmic membrane and subsequently leaks to the extracellular fluid. Overexpression of the Bacillus stearothermophilus $\alpha$-amylase gene in $E$. coli causes outer membrane damage leading to extracellular secretion of periplasmic proteins (Suominen et al., 1987).

Nakajima et al. (1986) identified four conserved regions in the amino acid sequences of eleven $\alpha$-amylases from a wide range of organisms. The alignment of the amino acid sequence of $A$. hydrophila MCC- $1 \alpha$-amylase with seven other $\alpha$-amylases showed not only four regions highly conserved in all enzymes, but also suggested the conservation of several additional regions.
Matsuura et al. (1984) proposed a model in which the amylose chain fits into a large cleft that contains the active site of the fungal $\alpha$-amylase and identified several amino acid residues, which lie on both sides of the cleft which were likely to be involved in substrate binding. These putative active sites and substrate binding residues (Fig. 3) suggest that these residues play important roles in catalytic function and substrate binding. Mammalian $\alpha$-amylases are inhibited by tendamistat (Hofmann et al., 1985). This inhibition profile is extremely similar to that of the Streptomyces limosus $\alpha$-amylase (Long et al., 1987). The sequence Phe-Glu-Trp, observed in the amino-terminal part of $\alpha$-amylases from mammals, invertebrates, $S$. limosus and $S$. venezuelae, but absent from the amylases of fungi, plants and most eubacteria, has been suggested as a possible candidate for interaction with the inhibitor. This triplet is also present in the $A$. hydrophila $\alpha$-amylase sequence at amino acid positions 32-34. It would be of interest to determine the susceptibility of this enzyme to tendamistat. Three putative calcium-binding residues were also observed in the $A$. hydrophila $\alpha$-amylase, which are consistent with the fact that this enzyme requires calcium ions for activity. In addition, the alignment also revealed several additional stretches of complete identity or a high degree of homology that are present in all eight $\alpha$-amylases. However, the functional significance of these is unclear.

Comparison of the amino acid sequence of $\alpha$-amylase from $A$. hydrophila, mammals, invertebrates and streptomycetes revealed that considerable homology extends throughout the entire mature regions, whilst there were no significant similarities between the $A$. hydrophila enzyme and $\alpha$-amylases derived from Hordeum vulgare (barley; Rogers \& Milliman, 1983), A. oryzae (Toda et al., 1982) and Bacillus spp. (Yang et al., 1983), except for four highly conserved regions and a very limited sequence. The amino acid sequence of streptomycete $\alpha$ amylase has a high degree of similarity with sequences of mammalian and invertebrate amylases which have been reported by Long et al. (1987) and Virolle et al. (1988). Long et al. (1987) suggest that these $\alpha$-amylases are derived from a common ancestral gene. Our results suggested that these amylases, including that of $A$. hydrophila MCC-1 $\alpha$-amylase, probably have a common evolutionary origin. However, it remains to be determined whether the mammalian, invertebrate, streptomycete and Aeromonas enzymes are derived from an ancestral primitive gene with a recently evolved branch point, or whether the remaining $\alpha$-amylases have an extremely divergent evolution from an ancient coancestral gene.

The authors wish to thank Dr C. G. Kuo for critical reviews of the manuscript. This work was supported by research grants NSC 81-0412- 
B-006-524 from the National Science Council, Taiwan, Republic of China.

\section{References}

BeGGS, J. D. (1978). Transformation of yeast by a replicating hybrid plasmid. Nature, London 275, 104-108.

Boer, P. H. \& HickeY, D. A. (1986). The $\alpha$-amylase gene in Drosophila melanogaster: nucleotide sequence, gene structure and expression motifs. Nucleic Acids Resarch 14, 8399-8411.

Bolivar, F., Rodriguez, R. L., Greene, P. J., Betlach, M. C., Heyneker, H. L., Boyer, H. W., Crosa, J. H. \& Falkow, S. (1977). Construction and characterization of new cloning vehicles, II. A multipurpose cloning system. Gene 2, 95-113.

Buisson, G., Duee, E., Haser, R. \& Payan, F. (1987). Threedimensional structure of porcine pancreatine $\alpha$-amylase at $2.9 \AA$ resolution. Role of calcium in structure and activity. EMBO Journal 6, 3909-3916.

Chakraborty, T., Montenegro, M. A., Sanyal, S. C., Helmuth, R., Bulling, E. \& Timmis, K. N. (1984). Cloning of enterotoxin gene from Aeromonas hydrophila provides conclusive evidence of production of a cytotoxic enterotoxin. Infection and Immunity 46, 435-441.

Chakraborty, T., Huhle, B., Bergbauer, H. \& Goebel, W. (1986). Cloning, expression, and mapping of the Aeromonas hydrophila aerolysin gene determinant in Escherichia coli K-12. Journal of Bacteriology 167, 368-374.

Chang, M. C., Chang, S. Y., Chen, S. L. \& Chuang, S. M. (1992). Cloning and expression in Escherichia coli of the gene encoding an extracellular deoxyribonuclease (DNase) from Aeromonas hydrophila. Gene 122, 175-180.

Chen, J. P., Nagayama, F. \& Chang, M. C. (1991). Cloning and expression of a chitinase gene from Aeromonas hydrophila in Escherichia coli. Applied and Environmental Microbiology 57, 24262428.

Cornelis, P., Digneffe, C. \& Willemot, K. (1982). Cloning and expression of a Bacillus coagulans amylase gene in Escherichia coli. Molecular and General Genetics 186, 507-511.

Freundlieb, S. \& Boos, W. (1986). $\alpha$-Amylase of Escherichia coli, mapping and cloning of the structural gene, malS, and identification of its product as a periplasmic protein. Journal of Biological Chemistry 261, 2946-2953.

Gobius, K. S. \& Pemberton, J. M. (1988). Molecular cloning, characterization, and nucleotide sequence of an extracellular amylase gene from Aeromonas hydrophila. Journal of Bacteriology 170, $1325-1332$.

Hagenbuechle, O., Bovey, R. \& Young, R. A. (1980). Tissue specific expression of mouse $\alpha$-amylase genes: nucleotide sequence of isozyme mRNAs from pancreas and salivary gland. Cell 21, 179-187.

Hofmann, O., Vertesy, L. \& Braunitzer, G. (1985). The primary structure of $\alpha$-amylase inhibitor Z-2685 from Streptomyces parvulus, FH-1641. Biological Chemistry Hoppe-Seyler 366, 1161-1168.

Hoshiko, S., Makabe, O., Nojiri, C., Katsumata, K., Satoh, E. \& NAGAOKA, K. (1987). Molecular cloning and characterization of the Streptomyces hygroscopicus $\alpha$-amylase gene. Journal of Bacteriology 169, $1029-1036$.

HOWARD, S. P. \& BUCKLEY, J. T. (1983). Intracellular accumulation of extracellular proteins by pleiotropic export mutants of Aeromonas hydrophila. Journal of Bacteriology 154, 413-418.

Howard, S. P. \& Buckley, J. T. (1985). Protein export by a Gramnegative bacterium: production of aerolysin by Aeromonas hydrophila. Journal of Bacteriology 161, 1118-1124.

Howard, S. P. \& BuCKLEY, J. T. (1986). Molecular cloning and expression in Escherichia coli of the structural gene for the hemolytic toxin aerolysin from Aeromonas hydrophila. Molecular and General Genetics 204, 289-295.

Howard, S. P., Garland, W. J., Green, M. J. \& Buckley, J. T. (1987). Nucleotide sequence of the gene for the hole-forming toxin aerolysin of Aeromonas hydrophila. Journal of Bacteriology 169, 2869-2871.

JIANG, B. \& HowARD, S. P. (1991). Mutagenesis and isolation of
Aeromonas hydrophila genes which are required for extracellular secretion. Journal of Bacteriology 173, 1241-1249.

JiAnG, B. \& Howard, S. P. (1992). The Aeromonas hydrophila exeE gene, required both for protein secretion and normal outer membrane biogenesis, is a member of a general secretion pathway. Molecular Microbiology 6, 1351-1361.

KLUH, I. (1981). Amino acid sequence of hog pancreatic $\alpha$-amylase isoenzyme I. FEBS Letters 136, 231-234.

LAEMmLI, U. K. (1970). Cleavage of structural proteins during the assembly of the head of bacteriophage T4. Nature, London 227, 681-685.

Leung, K. Y. \& Stevenson, R. M. W. (1988). Characteristics and distribution of extracellular proteases from Aeromonas hydrophila. Journal of General Microbiology 134, 151-160.

Lipman, D. J. \& Pearson, W. R. (1985). Rapid and sensitive protein similarity searches. Science 227, 1435-1441.

Long, C. M., Virolle, M.-J., Chang, S.-Y., Chang, S. \& Bibb, M. J. (1987). The $\alpha$-amylase gene of Streptomyces limosus: nucleotide sequence, expression motifs and amino-acid sequence homology to mammalian and invertebrate $\alpha$-amylases. Journal of Bacteriology 169, 5745-5754.

MCCluRE, W. R. (1985). Mechanism and control of transcription initiation in prokaryotes. Annual Review of Biochemistry 54, 171-204.

MacDonald, R. J., Crerar, M. M., Swain, W. F., Pictet, R. L., Thomas, G. \& Rutter, W. J. (1980). Structure of a family of rat amylase genes. Nature, London 287, 117-122.

MaCINTYRE, S. \& BUCKLEY, J. T. (1978). Presence of glycerophospholipid: cholesterol acyltransferase and phospholipase in culture supernatant of Aeromonas hydrophila. Journal of Bacteriology 135 , 402-407.

Matsuura, Y., Kusunoki, M., Harada, W. \& KaKudo, M. (1984). Structure and possible catalytic residues of Taka-amylase A. Journal of Biochemistry 95, 697-702.

Nakajima, R., Imanaka, T. \& Aiba, S. (1986). Comparison of amino acid sequences of eleven different $\alpha$-amylases. Applied and Microbiological Biotechnology 23, 355-360.

Nishide, T., Emi, M., Nakamura, Y. \& Matsubara, K. (1986). Corrected sequences of cDNAs for human salivary and pancreatic $\alpha$-amylases. Gene 50, 371-372.

Nord, C. E., Sjoberg, L., Wadstrom, T. \& Wretlind, B. (1975). Characterization of three Aeromonas and nine Pseudomonas species by extracellular enzymes and hemolysins. Medical Microbiology and Immunology 161, 79-87.

Pugsley, A. P., D'Enfert, C., Reyss, I. \& Kornacker, M. G. (1990). Genetics of extracellular protein secretion by Gram-negative bacteria. Annual Review of Genetics 24, 67-90.

Rivero, O., Anguita, J., Paniagua, C. \& Naharro, G. (1990). Molecular cloning and characterization of an extracellular protease gene from Aeromonas hydrophila. Journal of Bacteriology 172 3905-3908.

RoGERS, J. C. (1985). Conserved amino acid sequence domains in $\alpha$ amylase from plants, mammals and bacteria. Biochemical and Biophysical Research Communications 128, 470-476.

Rogers, J. C. \& Milliman, C. (1983). Isolation and sequence analysis of a barley $\alpha$-amylase cDNA clone. Journal of Biological Chemistry 258, 8169-8174.

SambrooK, J., Fritsch, E. F. \& Maniatis, T. (1989). Molecular Cloning: A Laboratory Manual, 2nd edn. Cold Spring Harbor, NY: Cold Spring Harbor Laboratory.

SANGer, F., Nicklen, S. \& Coulson, A. R. (1977). DNA sequencing with chain-terminating inhibitors. Proceedings of the National Academy of Sciences of the United States of America 74, 5463-5467.

Shine, J. \& Dalgarno, L. (1974). The 3'-terminal sequence of Escherichia coli $16 \mathrm{~S}$ ribosomal RNA: complementary to nonsense triplets and ribosome binding sites. Proceedings of the National Academy of Sciences of the United States of America 71, 1342-1346.

Stormo, G. D., Schneider, T. D. \& Gold, L. M. (1982). Characterization of translational initiation sites in Escherichia coli. Nucleic Acids Research 10, 2971-2996.

Suominen, H., Karp, M., Lahde, M., Kopio, A., Glumoff, T., Meyer, P. \& MantSala, P. (1987). Extracellular production of cloned $\alpha$ amylase by Escherichia coli. Gene 61, 165-176. 
Thornton, J., Howard, S. P. \& Buckley, J. T. (1988). Molecular cloning of a phospholipid-cholesterol acyltransferase from Aeromonas hydrophila. Sequence homologies with lecithin-cholesterol acyltransferase and other lipases. Biochimica et Biophysica Acta 959, 153-159.

TODA, H., Kondo, K. \& Narita, K. (1982). The complete amino acid sequence of Taka-amylase A. Proceedings of the Japan Academy 58, $208-212$.

Vieira, J. \& Messing, J. (1982). The pUC plasmids, and M13mp7 derived system for insertion mutagenesis and sequencing with synthetic universal primers. Gene 19, 259-268.

Virolle, M. J., Long, C. M., Chang, S. \& BibB, M. J. (1988). Cloning, characterisation and regulation of an $\alpha$-amylase gene from Streptomyces venezuelae. Gene 74, 321-334.

Von Heijne, G. (1983). Patterns of amino acids near signal-sequence cleavage sites. European Journal of Biochemistry 133, 17-21.
Von Heijne, G. (1984). How signal sequences maintain cleavage specificity. Journal of Molecular Biology 173, 243-251.

Von HeIJNE, G. (1988). Transcending the impenetrable: how proteins come to terms with membranes. Biochimica et Biophysica Acta 947, 307-333

Yabuki, M., Mizushina, K., Amatatsu, T., Ando, A., Fuji, T., Shimada, M. \& Yamashita, M. (1986). Purification and characterization of chitinase and chitobiase produced by Aeromonas hydrophila subsp. anaerogenes A52. Journal of General and Applied Microbiology 32, 25-38.

YANG, M., GalizzI, A. \& HenNER, D. (1983). Nucleotide sequence of the amylase gene from Bacillus subtilis. Nucleic Acids Research 11, 237-249.

Yanisch-Perron, C., Vieira, J. \& Messing, J. (1985). Improved M13 phage cloning vectors and host strains: nucleotide sequences of the M13mpl8 and pUC19 vectors. Gene 33, 103-119. 